\section{Epithets, divine (Greece and Rome)}

SYLVAIN LEBRETON

Divine epithets (eponumiai, epikleseis; cognomina, cognomenta) are a common feature of some ancient polytheisms, though the Hellenic world has recently benefited from far more studies than any other culture. The incredible variety of epithets, both in Greece and Rome, calls for a typology.

A first categorization has to be made according to their use: Pausanias already distinguished epithets given by poets or local cult-epithets from those known by everyone (7.21.7); accordingly, modern scholars usually differentiate cult-epithets or poetic epithets from those that designate iconographic types (respectively, athena Polias, glaukopis, and Promachos). However, these categories are not absolute (Parker 2003): some epithets can be used both in poetry and in cult, not to mention cases when they appear out of their original context, for example, in the work of lexicographers (Brulé and Lebreton 2007). Yet, among these categories, cult-epithets undoubtedly remain the richest field of experimentation about ancient polytheisms. Their combination with theonyms forms a dual system of divine denomination (Brulé 1998) which designates a divine figure (MARS Ultor), namely, the actualization of a divine power (Mars) in a specific context. Cult-epithets aim at marking out a divine figure from other ones, or fixing it in a given space (Parker 2003), in order to specify which divine protection is expected.

Cult-epithets can be divided into two main categories, according to toponymy and function. The innumerable "toponymic" epithets are built on a place-name, which in most cases is the same as the cult-place (APOLlo Palatinus on the Palatine). "Transferred" toponymic epithets reveal the diffusion of a widespread cult (ARTEMIs Ephesia) or the transfer of a local cult to another place (DIONYsos Eleuthereus in Athens). "Functional" epithets form a wider category. Strictly speaking, they identify the field in which the help of the deity is expected: the epithet can be the name of the field itself, a derivative, or an agent-name (respectively, zEUs Keraunos, Keraunios, and Keraunobolos); but other epithets designating a dynamic of intervention (Soter/Soteira) can also be categorized as functional.

The other categories actually prove to be variants of toponymic or (mostly) functional epithets (Parker 2003): some refer to ritual facts (Apollo Hekatombaios); others clearly derive from a theonym and closely bind a deity to another one (Athena Areia, Zeus Ares; cf. Parker 2005); "individual epithets," derived from personal names, link a god to the founder of a cult and often to his progeny (Wallensten 2008); some emphasize the power of the deity (JUPITER Optimus Maximus) or its faculty to respond to the worshipers' wishes (Epekoos). Finally, some quite frequent "topographic" epithets belong to both functional and toponymic categories, since they can refer both to landscapes favored by a god and to a peculiar place through a generic denomination: so, Zeus Akraios can be a generic Zeus of mountaintops; but for Magnesians, he was also the Zeus whose sanctuary was at the top of nearby Mount Pelion.

Cult-epithets are a precious tool for the understanding of ancient polytheisms. On a larger scale, the quantitative distribution of cultepithets among gods and goddesses is really instructive, since it is far from being homogeneous (cf. Banque de données des épiclèses grecques for Greece; Carter 1898 for Rome): some deities are very rich in double designations (Zeus above all; then come Apollo, Artemis, Athena, and so on); other gods bear only few epithets (ARES), or have none (HEPHAISTOS). A similar observation can be made on a qualitative level: again, Zeus intervenes in many aspects of ancient Greeks' life, whereas most of DEMETER's epithets refer to agriculture and plant growth. Likewise, some epithets are attributed to many different gods (Soter/Soteira), while other ones are exclusive to a single deity (POSEIDON Asphaleios), not to 
mention those that are shared by divine pairs (Zeus Phratrios and Athena Phratria).

On a closer scale, for a given deity, cultepithets reflect the features attributed by a given community, at a given time and in a given place, for a specific purpose. Although certain matches appear perfect (dedications to HERMES Agoraios by agoranomoi), the meaning of cultepithets does not always fit their literal signification, or at least seems not restricted to it: a dedication from a Macedonian woman to Artemis Elaphebolos ("who shoots deer"), most probably for the sake of her daughter (SEG 43.399A), shows that this Artemis was not (only) worshiped by (male) hunters and emphasizes the connection between this goddess, hinds, and youngsters (cf. Eur. IT). Such a case raises the issue of the coherence of a divine power despite its fragmentation in many figures, each of them being referred to by a single epithet (cf. Versnel 2011: 60-87). But as far as it can be representative of a whole, a dedication from the area of Nikaia (I.Iznik 1085), addressed to three distinct Zeuses (Bronton, Karpodotes, and Eucharistos) who are then merged into a single theos, shows that the articulation of these two levels - unity and distinction - does not seem to have raised many problems to ancient Greeks and Romans.
SEE ALSO: Chthonic deities, Greece and Rome; Olympian deities; Religion, Greek; Religion, Roman; Twelve Gods.

\section{REFERENCES AND SUGGESTED READINGS}

Banque de données des épiclèses grecques - Greek cult-epithets database (BDEG) online: https:// epiclesesgrecques.univ-rennes1.fr/

Brulé, P. (1998) "Le langage des épiclèses dans le polythéisme hellénique." Kernos 11: 13-34.

Brulé, P. and Lebreton, S. (2007) "La Banque de données des épiclèses (BDDE) du Crescam: sa philosophie." Kernos 20: 217-28.

Carter, J. B. (1898) De Deorum romanorum cognominibus quaestiones selectae. Leipzig.

Parker, R. (2003) "The problem of the Greek cult epithet." Opuscula Atheniensia 28: 173-83.

Parker, R. (2005) "Artémis Ilithye et les autres: le problème du nom divin utilisé comme épiclèse." In N. Belayche et al., eds., Nommer les dieux. Théonymes, épithètes, épiclèses dans l'Antiquité: 219-26. Turnhout.

Versnel, H. S. (2011) Coping with the gods. Wayward readings in Greek theology. Leiden.

Wallensten, J. (2008) "Personal protection and tailor-made deities: the use of individual epithets." Kernos 21: 81-95. 